\title{
PENGARUH PRODUCT INVOLVEMENT, MILK KNOWLEDGE DAN PERCEIVED VALUE TERHADAP PURCHASE INTENTION ( KASUS : PRODUK SUSU ULTRAMILK)
}

\author{
Ricky \\ Program Studi Magister Manajemen Universitas Tarumanagara \\ RLim_21@yahoo.com \\ Chairy \\ Program Studi Magister Manajemen Universitas Tarumanagara
}

\begin{abstract}
This study aimed to know the effect of the product involvement, product knowledge and perceived value that consumer's have towards purchase intention on Ultramilk products with product knowledge and perceived value towards purchase intention as the mediating variable. The variables used were product involvement, produk knowledge, perceived value and purchase intention. This study uses quantitative method. The data collection technique use online questionnaires distributed to 100 respondents namely consumers that have drink Ultramilk milk products before with non probability sampling method. The analysis method that used in this study was pls-sem (structural equation modelling). The result showed that product involvement positively and significantly affect to product knowledge,perceived value and purchase intention directly and perceived value have positively and significantly affect to purchase intention but for produk knowledge no have significantly affect to purchase intention but product knowledge have significantly affect to perceived value which perceived value have positive affect to purchase intention.
\end{abstract}

\begin{abstract}
Abstrak : Penelitian ini bertujuan untuk mengetahui efek dari keterlibatan produk, pengetahuan produk dan persepsi nilai yang dimiliki konsumen terhadap minat beli produk susu Ultramilk dengan pengetahuan produk dan persepsi nilai menjadi variabel mediasi terhadap minat beli pada produk susu Ultramilk. Variabel yang digunakan dalam penelitian ini adalah keterlibatan produk, pengetahuan produk, persepsi nilai dan minat beli. Penelitian ini menggunakan metode kuantitatif. Teknik pengumpulan data yang digunakan adalah melalui kuesioner online yang disebarkan kepada 100 responden yang dimana hasil kuesioner yang diolah adalah responden yang pernah meminum produk susu Ultramilk sebelumnya dan menggunakan teknik sampling non probabilitas. Metode analisis yang digunakan dalam penelitian ini adalah pls-sem (structural equation modelling). Hasil dari penelitian ini adalah keterlibatan produk memiliki efek yang positif dan signifikan terhadap pengetahuan produk, persepsi nilai dan minat beli secara langsung sedangkan persepsi nilai memiliki efek yang positif dan signifikan terhadap minat beli namun untuk pengetahuan produk tidak memiliki efek yang signifikan terhadap minat beli namun pengetahuan produk memiliki efek yang signifikan terhadap pesepsi nilai dimana persepsi nilai mempunyai efek yang positif terhadap minat beli.
\end{abstract}

Keywords: product involvement, product knowledge, perceived value,milk, and purchase intention, marketing. 


\section{PENDAHULUAN}

Seiring peningkatan jumlah penduduk, pertumbuhan ekonomi, perbaikan tingkat pendidikan, kesadaran gizi, perubahan gaya hidup serta pengetahuan masyarakat tentang kesehatan mengakibatkan banyak perubahan di berbagai segi termasuk pola konsumsi masyarakat dan gaya hidup masyarakat perkotaan yang memberikan perhatian lebih terhadap makanan bergizi. Pola konsumsi kini mulai beralih ke konsumsi pangan yang kaya protein, vitamin dan mineral. Hal ini mengakibatkan terjadi peningkatan rata-rata pengeluaran penduduk per kapita terhadap konsumsi susu.

Pada tahun 2016, diketahui bahwa tingkat konsumsi susu masyarakat Indonesia masih rendah dibandingkan dengan beberapa negara di kawasan ASEAN yang sudah mencapai di atas 15 kilogram per kapita per tahun. Jika di pandang pada sisi lainnya yaitu sisi industri pengolahan susu di Indonesia, peningkatan pertumbuhan sektor industri pengolahan susu pada tahun 2014 sebesar 14\%, meningkat di bandingkan pada tahun 2013 yang hanya sebesar 12\%. Dengan berlandaskan data tersebut dapat kita lihat bahwa peningkatan tersebut menunjukkan potensi pasar bagi industri pengolahan susu di Indonesia masih cukup besar. Hal ini menunjukkan potensi pasar bagi industri pengolahan susu di Indonesia masih cukup besar. Persaingan untuk memberikan yang terbaik kepada konsumen telah menempatkan konsumen sebagai pengambil keputusan membuat masyarakat dapat menentukan pilihan sesuai dengan kebutuhannya. Persaingan antar perusahaan juga terjadi pada industri susu.

Sebelum melakukan suatu pembelian, konsumen pada umumnya akan mengumpulkan informasi mengenai produk, baik yang di dasarkan pengalaman pribadi maupun yang berasal dari lingkungan sekitar. Setelah informasi terkumpul, konsumen akan memulai penilaian terhadap produk tersebut, mengevaluasi serta membuat suatu keputusan pembelian setelah membandingkan produk dan mempertimbangkannya. Product involvement merupakan salah satu variabel lain yang di anggap turut serta berpengaruh terhadap niat beli konsumen. Product involvement di definisikan sebagai tingkatan sedalam apa konsumen terikat dengan suatu kategori produk tertentu.(Spacey,2017).

Tingkat konsumsi susu di Indonesia masih rendah di bandingkan dengan negara Asia lainnya. Salah satu penyebabnya adalah kurangnya pengetahuan akan manfaat susu bagi sebagian masyarakat Indonesia. Oleh karena itu program edukasi susu dan program sejenis diharapkan dapat mengejar ketertinggalan tersebut dalam meningkatkan konsumsi susu per kapita di Indonesia yang dimana sekaligus meningkatkan purchase intention terhadap produk susu siap minum.

Menurut Kotler \& Keller (2012:148), Ketika konsumen telah memiliki persepsi kualitas terhadap suatu produk, maka konsumen akan membandingkannya dengan pengorbanan yang akan mereka lakukan dalam upaya mendapatkan suatu produk tersebut. Proses perbandingan antara persepsi kualitas dengan pengorbanan ini disebut perceived value.

Berkaitan dengan keinginan konsumen untuk membeli dikenal istilah purchase intention. Purchase intention merupakan bagian dari proses menuju ke arah tindakan pembelian yang dilakukan oleh seorang konsumen. Pada tahap purchase intention konsumen telah memiliki minat untuk melakukan tindakan membeli, dimana minat tersebut terbangun dari akumulasi aktivitas komunikasi pemasaran yang dilakukan perusahaan dan pengalaman konsumen.

Tujuan dari penelitian ini adalah : (1) Untuk menyelidiki apakah product involvement memiliki pengaruh yang signifikan terhadap product knowledge. (2) Untuk menyelidiki apakah product involvement memiliki pengaruh yang signifikan terhadap perceived value. (3) Untuk menyelidiki apakah product invovelment memiliki pengaruh yang signifikan terhadap purchase intention. (4) Untuk menyelidiki apakah product knowledge memiliki pengaruh yang signifikan terhadap perceived value. (5) Untuk menyelidiki apakah product knowledge 
memiliki pengaruh yang signifikan terhadap purchase intention. (6) Untuk menyelidiki apakah perceived value memiliki pengaruh yang signifikan terhadap purchase intention. (7) Untuk menyelidiki apakah median product knowledge pada product involvement memiliki pengaruh yang signifikan terhadap purchase intention. (8) Untuk menyelidiki apakah median perceived value pada product involvement memiliki pengaruh yang signifikan terhadap purchase intention.

\section{KAJIAN TEORI}

Product involvement. Hamidi (2014) menyatakan bahwa product involvement adalah perasaan tertarik dan antusiasme yang dimiliki konsumen terhadap suatu produk tertentu sedangkan Menurut Montandon, Ogonowski \& Botha (2016), product involvement adalah bagian fundamental dari proses keputusan pembelian seorang konsumen, ketika menemukan suatu produk atau mengunjungi pasar, setiap konsumen memiliki respon yang berbeda-beda berdasarkan product involvement dari produk tersebut dan Choudhury (2018) menyatakan bahwa product involvement adalah teori pembelajaran konsumen yang mengandaikan bahwa tingkat minat untuk melakukan pembelian suatu produk atau jasa tergantung pada risiko yang terlibat dalam keputusan pembelian.

Product knowledge. Leonandri (2013) menyatakan bahwa product knowledge adalah representasi kognitif dari suatu produk, merek atau hal lain yang tersimpan dalam memori atau ingatan konsumen. Hal ini diperkuat dengan pernyataan dari Rita (2018) bahwa product knowledge adalah pengetahuan yang dimiliki oleh konsumen mengenai sebuah produk.

Perceived value. Menurut Gantara, Kumadji, dan Yulianto (2013), mengemukakan bahwa perceived value adalah penilaian pelanggan yang dilakukan dengan cara membandingkan antara manfaat yang akan diterima dengan pengorbanan yang dikeluarkan untuk memperoleh sebuah produk/jasa. Sedangkan menurut Meena (2017) menyatakan bahwa perceived value adalah manfaat dari suatu produk atau jasa yang dimiliki di dalam pikiran konsumen.

Purchase intention. purchase intention adalah salah satu input utama yang digunakan oleh manajer pemasaran untuk memprediksi penjualan di masa mendatang dan untuk menentukan bagaimana tindakan yang perlu di ambil untuk mempengaruhi tingkah laku pembelian konsumen (Morwitz,2014). Sebelum melakukan pembelian, konsumen mulai dengan mengumpulkan informasi produk berdasarkan pengalaman pribadi dan eksternal lingkungan. Ketika jumlah informasi mencapai tingkat tertentu, konsumen memulai penilaian dan proses evaluasi, dan membuat keputusan pembelian setelah perbandingan dan penilaian. Oleh karena itu purchase intention sering digunakan untuk menganalisis perilaku konsumen dalam studi terkait.

Berdasarkan paparan di atas, maka hipotesis penelitian adalah sebagai berikut :

H1 : Terdapat pengaruh yang positif dan signifikan dari product involvement terhadap variabel product knowledge

H2 : Terdapat pengaruh yang positif dan signifikan dari product involvement terhadap variabel perceived value

H3 : Terdapat pengaruh yang positif dan signifikan dari product involvement terhadap variabel purchase intention

H4 : Terdapat pengaruh yang positif dan signifikan dari product knowledge terhadap perceived value.

H5 : Terdapat pengaruh yang positif dan signifikan dari product knowledge terhadap purchase intention.

H6 : Terdapat pengaruh yang positif dan signifikan dari perceived value terhadap purchase intention. 


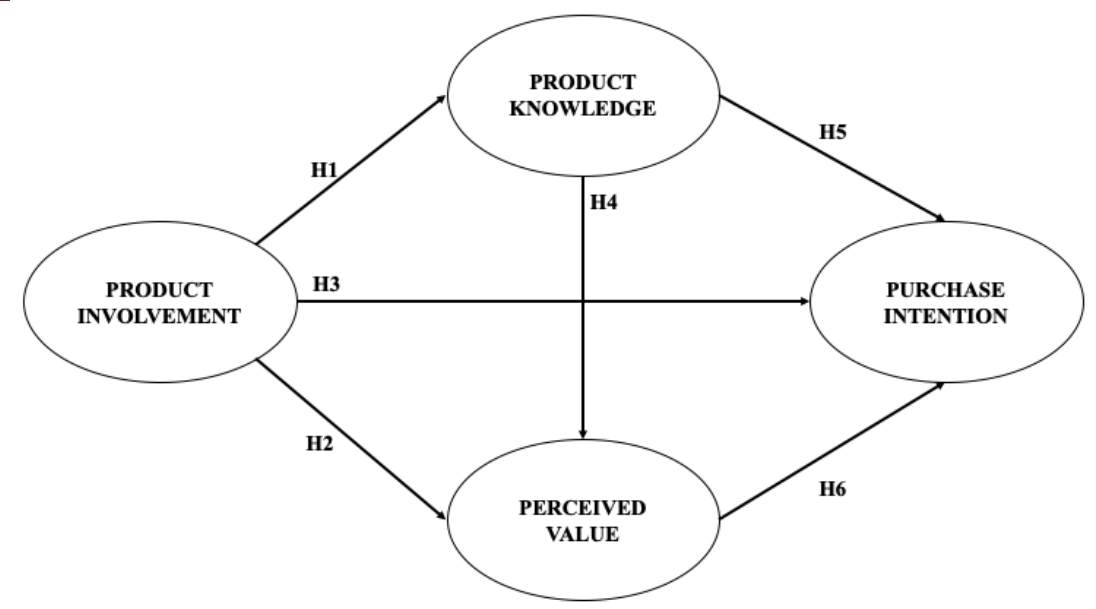

\section{METODE}

Populasi, Teknik Pemilihan Sampel, dan Ukuran Sampel. Populasi dalam penelitian ini adalah seluruh konsumen yang pernah meminum susu Ultramilk. Metode pengambilan sampel dalam penelitian ini adalah teknik non probability sampling dengan pendekatan quota sampling. Ukuran sampel yang digunakan dalam penelitian ini sebanyak 100 responden.

Variabel dan Pengukuran. Variabel yang digunakan dalam penelitian ini adalah product involvement, product knowledge, perceived value dan purchase intention.

Metode Analisa Data. Metode analisis data yang digunakan untuk menjawab masalah penelitian ini adalah dengan pls-sem (partial least square - structural equation modelling) Uji yang dilakukan dalam metode analisis data ini adalah uji validitas dan reliabilitas untuk kebutuhan pretest kemudian dilanjutkan dengan pengujian model awal yang terdiri atas pengujian validitas konvergen, validitas diskriminan, cross loadings, outer loadings dan uji reliabilitas dan dilanjutkan dengan pengujian model akhir yang terdiri atas pengujian validitas konvergen, validitas diskriminan, cross loadings, outer loadings, uji reliabilitas, path coefficient, analisis besar pengaruh, analisis persentase pengaruh, $\mathrm{f}^{2}$ effect size dan $\mathrm{q}^{2}$ effect size .Taraf signifikansi yang digunakan dalam penelitian ini adalah 5\%. Pengujian dalam penelitian ini menggunakan program SPSS dan SmartPLS.

\section{HASIL DAN PEMBAHASAN}

Profil Responden. Berdasarkan data yang telah dikumpulkan pada penelitian ini Sebagian besar responden dalam penelitian berjenis kelamin wanita $60 \%$, mayoritas responden berusia 16 - 25 tahun sebesar $61 \%$, mayoritas berpendidikan terakhir S1 sebesar $65 \%$, mayoritas memiliki rata-rata pengeluaran tiap bulannya sebesar > Rp.4.000.000.000 sebesar 46\%, dan semua responden pernah mengkonsumsi susu Ultramilk.

Rangkuman hasil uji. berdasarkan uji pretest pada tiap variabel manifest telah menunjukkan hasil validitas dan reliabilitas yang telah sesuai kriteria maka setelah nya dilanjutkan dengan pengujian model awal dan model akhir.

Berikut adalah hasil rangkuman hasil uji yang telah dilakukan :

- Pengaruh product involvement kepada milk knowledge memiliki hasil uji signifikansi yang signifikan, memiliki besar nilai pengaruh langsung sebesar 0.459524 dengan nilai besar presentase pengaruh sebesar $21.12 \%$. maka berdasarkan hasil uji tersebut hipotesa H1 diterima karena variabel laten product involvement berpengaruh signifikan terhadap variabel laten milk knowledge.

- Pengaruh product involvement kepada perceived value memiliki hasil uji signifikansi yang signifikan dan memiliki besar nilai pengaruh langsung sebesar 0.438018 dengan nilai besar presentase pengaruh sebesar 26.87\%. maka berdasarkan hasil uji tersebut 
hipotesa $\mathrm{H} 2$ diterima karena variabel laten product involvement berpengaruh signifikan terhadap variabel laten perceived value.

- Pengaruh product involvement kepada purchase intention memiliki hasil uji signifikansi yang signifikan dan memiliki besar nilai pengaruh langsung sebesar 0.417736 dengan nilai besar presentase pengaruh sebesar 27.03\%. maka berdasarkan hasil uji tersebut hipotesa $\mathrm{H} 3$ diterima karena variabel laten product involvement berpengaruh signifikan terhadap variabel laten purchase intention.

- Pengaruh milk knowledge kepada perceived value memiliki hasil uji signifikansi yang signifikan dan memiliki besar nilai pengaruh langsung sebesar 0.381855 dengan nilai besar presentase pengaruh sebesar $22.27 \%$. maka berdasarkan hasil uji tersebut hipotesa H4 diterima karena variabel laten milk knowledge berpengaruh signifikan terhadap variabel laten perceived value.

- Pengaruh milk knowledge kepada purchase intention memiliki hasil uji signifikansi yang tidak signifikan dan memiliki besar nilai pengaruh langsung sebesar -0.068569 dengan nilai besar presentase pengaruh sebesar $-2.54 \%$. maka berdasarkan hasil uji tersebut hipotesa H5 ditolak karena variabel laten milk knowledge tidak berpengaruh terhadap variabel laten purchase intention.

- Pengaruh perceived value kepada purchase intention memiliki hasil uji signifikansi yang signifikan dan memiliki besar nilai pengaruh langsung sebesar 0.425299 dengan nilai besar presentase pengaruh sebesar 27.28\%. maka berdasarkan hasil uji tersebut hipotesa H6 diterima karena variabel laten perceived value berpengaruh signifikan terhadap variabel laten purchase intention.

Simpulan. Hasil penelitian ini membuktikan bahwa product involvement memiliki pengaruh yang positif dan signifikan terhadap product knowledge, perceived value dan purchase intention pada produk susu Ultramilk. Kemudian perceived value memiliki pengaruh yang positif dan signifikan terhadap purchase intention sedangkan pada product knowledge memiliki pengaruh yang positif dan signifikan terhadap perceived value namun tidak terhadap purchase intention.

Saran. Hasil penelitian ini diharapkan dapat memberikan saran kepada pihak perusahaan agar dapat memperhatikan faktor product involvement dan perceived value guna meningkatkan minat beli konsumen pada produk susu Ultramilk. Bagi peneliti lain, disarankan agar jumlah pengambilan sampel di perbanyak lagi untuk penelitian selanjutnya, sehingga dapat memperkuat dan melengkapi penelitian sebelumnya serta menambah faktorfaktor lain yang dapat mempengaruhi minat beli.

\section{DAFTAR PUSTAKA}

Choudury,Akash (2018). Involvement of Consumers in Decision making [Online]

Diakses tanggal 25 November 2018 dari http://www.yourarticlelibrary.com/consumerbehaviour/decision-making-consumer-behaviour/involvement-of-consumers-indecision-making/64198

Gantara,Gery., Kumadji,Srikandi \& Yulianto,Edy (2013). Analisis Pengaruh Kualitas Layanan dan Perceived Value Terhadap Kepuasan Pelanggan dan Loyalitas Pelanggan. Jurnal Administrasi Bisnis (JAB) Vol.1 No.1 April 2013. h. 41.

Hamidi (2014). Product knowledge [Online]. Diakses tanggal 27 November 2018 dari https://www.slideshare.net/hoomanhamidiaval/product-involvement-37641587

Kotler, Philip \& Keller, Kevin Lane (2012). Marketing Management.( $14^{\text {th }}$ ed.) New Jersey: Penerbit Prentice Hall. h.148.

Meena, Deepak (2017). What is perceived value? [Online]. Diakses tanggal 24

November 2018 dari https://www.quora.com/What-is-perceived-value

Montandon, Andrew C. (2016). Product Involvement and the Relative Importance of 
Health Endoresment. Diakses tanggal 24 November 2018 dari https://www.tandfonline.com/doi/full/10.1080/10454446.2015.1048031

Morwitz, Vicki (2014). Consumer's Purchase Intentions and their Behavior.h.1.

Rita (2018). Consumer Product Knowledge [Online]. Diakses tanggal 24 November

2018 dari http://bbs.binus.ac.id/international-marketing/2018/04/consumer-productknowledge/

Spacey, John (2017). 6 Types of Product Involvement [Online]. Diakses tanggal 27

November 2018 dari https://simplicable.com/new/product-involvement

Tempo (2016). Tingkat Konsumsi Susu Masyarakat Indonesia Rendah [Online]

Diakses tanggal 25 November 2017 dari https://bisnis.tempo.co/read/774702/tingkat-

konsumsi-susu-masyarakat-indonesia-rendah

Wijaya, Adi (2015). Contoh Analisa Cepat Analisa SEM dengan smartPLS.

Diakses tanggal 15 Oktober 2018 dari

https://www.researchgate.net/publication/304554712_Contoh_Analisa_Cepat_Analisa _SEM_dengan_smartPLS

Wong,Ken Kwong-Kay (2013). Partial least square structural equation modeling (PLSSEM) techniques using SmartPLS. Marketing Bulettin,2013,24, Technical Note 1. h. 3 \& h. 5. 
